\author{
Orest Krasiwski \\ (Poznań-Gniezno) \\ https://orcid.org/0000-0002-7028-6038
}

\title{
POMIĘDZY UKRAINĄ A POLSKĄ: DZIAŁALNOŚĆ SPOŁECZNA I POLITYCZNA HRABIEGO M. TYSZKIEWICZA (1857-1930)
}

\begin{abstract}
This paper analyzes political activities of Count M. Tyszkiewicz. The author sets out from an overview of his descent, academic education, and family relationship. Particular attention is devoted to Tyszkiewicz's involvement in political affairs, formation of his views, as well as social and political undertakings. Another element highlighted here is Tyszkiewicz's activity as a patron, his contribution to the development of Ukrainian and Polish culture, and relations with Ukrainian politicians and writers at the turn of the $20^{\text {th }}$ century. Furthermore, the author discusses his diplomatic achievement as a representative of Ukraine to the Holy See and the peace conference in Paris. Based on a study of correspondence between Tyszkiewicz and Ukrainian politicians, the author emphasizes his commitment to the Ukrainian cause on the international scene and efforts to seek recognition of the Ukrainian state.
\end{abstract}

\section{Key words}

Ukraine, Poland, M.Tyszkiewicz, diplomatic mission, international recognition, Holy See, Paris Peace Conference

Michał Tyszkiewicz, który ostatnie lata swojego życia spędził na ziemiach Wielkopolski - w Gnieźnie, Bydgoszczy i Żydowie, służył w swoim życiu zarówno narodowi polskiemu, jak i ukraińskiemu.

Michał Tyszkiewicz urodził się we wsi Andruszówka w obwodzie kijowskim i pochodził z dawnego rodu rusińskiego (ukraińskiego) wywyodzącego się od Kalenika Myszkowicza - jednego z działaczy okresu Świdrygiełły, syna Olgierda i brata króla polskiego Jagiełły ${ }^{1}$. To od Świdrygiełły Kalenik dostał do rąk własnych

1 Tyszkiewicz 2012, s. 171-172. 
zaświadczenia o posiadaniu dużych majątków ziemskich na Kijowszczyźnie i Podolu, a jeden $z$ jego synów, Tyszko, był hetmanem u litewskigo księcia. Od Tyszki pochodzi również nazwisko wielkiego rodu Tyszkiewiczów. Michał był wnukiem Henryka, marszałka szlachty gubernii kijowskiej. W jego domu wychował się słynny ukrainofil Franciszek Duchiński, który później napisał w książce „Zasady dziejów Polski”, że właśnie w domu Tyszkiewiczów, będącym jednocześnie polskim i ukraińskim, poczuł się po raz pierwszy Ukraińcem².

W ówczesnym życiu rodziny $\mathrm{M}$. Tyszkiewicza unikalnie połączyły się dwie kultury: francuska i ukraińska. Środowisko narodowe miało decydujący wpływ na kształtowanie się jego osobowości. A. Gospodin, jeden z badaczy życia i działalności M. Tyszkiewicza, wytłumaczył to dość charakterystyczne zjawisko w ten sposób: „Jego ukraiński patriotyzm rozwijał się powoli (...), uważał siebie za autochtona, który mieszka na Ukrainie od wielu wieków"3.

W wieku 13 lat Michał rozpoczął naukę w gimnazjum w Wilnie. Później studiował w Akademii Sztuk Pięknych w Petersburgu, którą ukończył w 1905 roku z wyróźnieniem (srebrny medal). Był stażystą u słynnych artystów w Paryżu, w tym Auguste’a Renoira. Po powrocie z zagranicy Michał zamieszkał w Andruszówce i zajął się majątkiem, który stał się własnością Tyszkiewiczów przez małżeństwo Stanislawa (ojca Michała) z Heleną Kołysko, ukraińską filantropką, która była zaangażowana $\mathrm{w}$ działalność charytatywną, wspierała biednych studentów pochodzących ze wsi. Dla dzieci - mieszkańców urkaińskiej wsi - Helena założyła szkołę, która wkrótce została zamknięta przez władze rosyjskie ${ }^{4}$.

W tym okresie ostatecznie kształtują się poglądy M. Tyszkiewicza. Utwierdza się w przywiązaniu do swojego rodzinnego kraju i jego mieszkańców: „Moje doświadczenia, (...) których nie zapomnę, można porównać tylko z tym, co poczułem, kiedy po raz pierwszy w moim życiu zbliżyłem się do Komunii Świętej”' Od tego czasu, jak pisał w swoich wspomnieniach Tyszkiewicz, „zawsze pragnął (...) ukraińskości”. „Moja miłość do ojczyzny wyrosła, kiedy po długim pobycie za granicą wróciłem do domu jako młody chłopak"7 - pisał w pamiętnikach. Uznawał siebie za „Rusina”, obywatela Rusi narodowości polskiej. Jego ideałem był kraj, w którym Polak i Ukrainiec, katolik i prawosławny, żyją jak bracia. Dążył do wcielenia tego ideału w życie.

W drugiej połowie XIX wieku na prawobrzeżnej Ukrainie powstaje populistyczno-kulturowy nurt - chłopomania, członkowie którego pragnęli zbliżenia

\footnotetext{
2 Tyszkiewicz 1928, s. 260.

3 Gospodin 1989.

${ }^{4}$ Lechniuk 2015, s. 145.

5 Tyszkiewicz 1928, s. 254.

${ }^{6}$ Ibidem.

7 Ibidem.
} 
z narodem, miłości do zwykłego, prostego ludu ukraińskiego. Jako rodzaj ruchu społecznego chłopomania reprezentowana była przez przestawicieli polskiej inteligencji, młodzież studencką, potomków spolszczonych rodzin prawosławnych. Stopniowo ruch przybiera demokratyczne formy. Demokratyzm chłopomanów objawił się w ich stosunku do zwykłych ludzi. Uznano historyczną niesprawiedliwość polskiej szlachty wobec narodu ukraińskiego (chłopów). Ponadto wyznawano ideę pokuty historycznej, która miała się przejawiać wsparciem edukacji i języka narodu ukraińskiego. Chłopomania - jako najbardziej radykalny nurt polskiego ruchu wyzwoleńczego - głosiła idee społeczne tolerancji religijnej i natychmiastowego uwolnienia chłopów od pańszczyzny.

M. Tyszkiewicz był wybitnym przedstawicielem tego nurtu, jednym z pierwszych arystokratów-chłopomanów, który postanowił zerwać więzi z rodziną i w młodym wieku powrócił do swoich ukraińskich korzeni. Ta młodzieńcza fascynacja ukraińskością wywarła wpływ na całe jego życie, działalność artystyczną, naukową i społeczno-polityczną̧.

W tym kontekście wielkie znaczenie miały jego relacje z ukraińskim historykiem polskiego pochodzenia, profesorem Uniwersytetu Kijowskiego Wołodymyrem Antonowiczem, którego poznał podczas pracy w jego archiwum. Pisał Tyszkiewicz w swoich pamiętnikach:

Był to dla mnie skromny, spokojny człowiek, miał oczy błyszczące ogniem, a na ustach pojawił się gorzki uśmiech. Niezmiernie kochał Ukrainę i bardzo cierpiał z tego powodu. Nasze na początku zimne relacje, szybko się ociepliły. Coś mnie do niego przyciągało i za każdym razem, gdy był w Kijowie, wieczór w jego domu na ulicy Żelanskiej, sprawiał mi wielką przyjemność 9 .

Będący przykładem życiowego poświęcenia Antonowicz stał się także łącznikiem pomiędzy Tyszkiewiczem a wieloma czołowymi postaciami ruchu ukraińskiego, między innymi M. Hruszewskim, metropolitą A. Szeptyckim, S. Petlurą, D. Doncowym. Dzięki W. Antonowiczowi hrabia wszedł w stosunki z lwówską „Proswitą”. Przez wpływ Antonowicza można wyjaśnić przywiązanie hrabiego do niektórych idei socjalistycznych: nie zgadzając się z socjalizmem jako takim (ponieważ zaprzeczał on swobodzie i kulturze), uważał jednak, że socjalistyczna „utopia” jest nieuniknioną przyszłością ${ }^{10}$.

Tyszkiewicz z jednej strony wspierał polskich pisarzy i artystów, a z drugiej założył Fundację Michajłowa na Ukrainie, która wspomagała artystów ukraińskich.

\footnotetext{
8 Vasylenko 2012, s. 155.

9 Tyszkiewicz, 9, s. 55.

${ }^{10}$ Lechniuk 2014, s. 167.
} 
Pomoc Fundacji przeznaczana była dla autorów najlepszego dramatu historycznego lub powieści o ukraińskim charakterze patriotycznym. Nominowani zostali Osyp Makowej za opowiadanie „Jaroszenko”, w którym autor opisał heroiczne wyczyny kozaków w bitwie pod Chocimiem w latach 1620-1621, a także Osyp Nazaruk za opowiadanie "Jarosław Ośmiomysł"11. Z okazji setnej rocznicy urodzin T. Szewczenki hrabia dał ukraińskiemu towarzystwu naukowemu w Kijowie 20000 rubli $^{12}$, a 3000 franków przekazał na otwarcie Wydziału Ukrainistyki na Uniwersytecie w Louvain (Belgia). Michał Tyszkiewicz publikował także ukraińskie książki i wspierał finansowo różne czasopisma: „Przegląd Krajowy” Wacława Lipińskiego, „Ridnyj Kraj” („Kraj rodzimy”) Oleny Pcziłki, „Biuletyn” („Wisnyk”) Dmytra Doncowa. W kijowskiej gazecie „Rada” Tyszkiewicz potępiał rusyfikację Ukrainy $^{13}$.

Pracując na rzecz Ukrainy, hrabia zorganizował Ukraińskie Towarzystwo Naukowe w Kijowie, a w rodzinnej Andruszówce założył szkołę, w której językiem wykładowym był język ukraiński. W 1908 roku sfinansował publikację w Kijowie dwujęzycznego ukraińsko-polskiego wydania literackiego „Noworocznik literacki polsko-ukraiński”, w którym ukazały się prace autorów polskich i ukraińskich. Dochód ze sprzedaży publikacji był przeznaczony na sprowadzenie szczątków Juliusza Słowackiego do Polski, a także budowę pomnika T. Szewczenki w Kijowie. W swojej historii literatury ukraińskiej chwalił Szewczenkę jako najwybitniejszego poetę całej Słowiańszczyzny, przewyższającego talentem nawet Puszkina i Mickiewicza $^{14}$. Stanowczo sprzeciwiał się zniesławiającej antyukraińskiej propagandzie - zarówno rosyjskiej czarnosecinnej, jak i polskiej endeckiej. Na ten temat publikuje w polskich i rosyjskich wydaniach artykuły o "nacjonalistycznym imporcie” z Petersburga i Warszawy ${ }^{15}$. Z jego inicjatywy w 1907 r. w Kijowie utworzono Polską Organizację Krajową na Rusi, reprezentującą polską elitę gubernii kijowskiej, wołyńskiej i podolskiej, która w kwestii ukraińskiej była alternatywą dla obozu nacjonalistycznego. Tyszkiewicza można uznać za jedną z ważniejszych postaci ruchu ukraińskiego w „podrosyjskiej” części Ukrainy.

Fascynacja ukraińską historią i kulturą miała ogromny wpływ na życie Tyszkiewicza, skłoniła go do powrotu do ukraińskich korzeni i wywołała pragnienie służenia narodowi ukraińskiemu. W przededniu rewolucji rosyjskiej w latach 1909-1917, mieszkając w Europie Zachodniej, hrabia ostatecznie wkroczył na ścieżkę wiodącą ku przywróceniu państwowości ukraińskiej do modelu zachodnioeuropejskiego, i pozostał bezkompromisowy wobec koncepcji niepodzielności

\footnotetext{
11 Shemshuchenko 2002, s. 212.

12 Chykalenko 2005, s. 83.

13 Cherkaska 2015.

14 Stryjek 2012, s. 42.

15 Cherkaska 2015.
} 
imperium rosyjskiego. Jednocześnie upatrywał cywilizacyjnej roli katolicyzmu na Ukrainie $^{16}$.

W latach 1909-1917 M. Tyszkiewicz mieszkał w Europie Zachodniej. Był to czas, według polskiego badacza T. Stryjka, „ostatecznej przemiany Tyszkiewicza z propagatora idei krajowej w zwolennika budowy niepodległego państwa ukraińskiego (...), oraz w polityka służącego całkiem nowej wizji porządku w Europie Wschodniej” ${ }^{17}$. Aktywnie działa wówczas jako propagator sprawy ukraińskiej, starając się naświetlić kwestię niepodległości Ukrainy tym, którzy wywierali wpływ na politykę światową. Nawiązuje kontakty $\mathrm{z}$ francuskimi i angielskimi dyplomatami. Utrzymuje bliskie relacje z metropolitą halickim A. Szeptyckim. W czasie pierwszej wojny światowej w Szwajcarii wydaje tygodnik „L'Ukraine”, w którym publikowano badania nad historią Ukrainy, artykuły ujawniające działania armii rosyjskiej w Galicji i Bukowinie, w szczególności o antyukraińskiej polityce rosyjskiego gubernatora Galicji G. Bobrińskiego. Tyszkiewicz opowiada się za zwolnieniem z rosyjskiego wygnania Szeptyckiego, który podczas wojny był internowany przez władze rosyjskie ${ }^{18}$.

Podczas rewolucji ukraińskiej i ustanowienia państwowości na Ukrainie ważną rolę odegrała działalność ukraińskiego rządu w zakresie polityki zagranicznej, mająca na celu ochronę i uznanie na arenie międzynarodowej młodej republiki. Pod koniec 1918 r. sytuacja na Ukrainie i wokół niej wymagała nawiązania stosunków międzynarodowych, które stworzyłyby zewnętrzne warunki dla budowania państwowości. W styczniu-lutym 1919 r. zaczęła się tworzyć nowa ukraińska służba dyplomatyczna, ustanowiono misje zagraniczne, w tym misję dyplomatyczną przy Watykanie. Rząd URL przywiązywał wielką wagę do nawiązania stosunków dyplomatycznych $\mathrm{z}$ Watykanem, ponieważ szerokie stosunki międzynarodowe i autorytet tronu papieskiego mogły przyczynić się do międzynarodowego uznania Ukrainy. Dlatego po długich dyskusjach w kręgach rządowych Ukrainy przedstawicielem dyplomatycznym do Watykanu mianowano hrabiego M. Tyszkiewicza ${ }^{19}$.

15 lutego 1919 r. został on oficjalnie nominowany i w maju tego roku udał się do Rzymu. 20 maja złożył Sekretarzowi Stanu Pietro Gasparremu oficjalne pismo przedstawiające zasady przyszłej współpracy ${ }^{20}$. W liście przeanalizowano sytuację polityczną i gospodarczą we wschodniej Galicji, „której ludzie chcieli żyć w jednym, niezależnym państwie”. Mówiąc o stosunkach polsko-ukraińskich, hrabia bronił praw Kościoła greckokatolickiego. Zwrócił uwagę na nieprzyjazne wobec państwa ukraińskiego działania polskiego duchowieństwa katolickiego w Galicji,

\footnotetext{
16 Stryjek 2012, s. 53.

17 Ibidem.

18 Vasylenko s. 155.

19 Smolii 2001, s. 343.

${ }^{20}$ Gentosh 2000, s. 168-169.
} 
które stały na przeszkodzie „bezpośrednim wpływom Kościoła katolickiego na Ukrainie”, i stwierdził, że „nie będzie tolerował zagranicznej propagandy narodowej pod przykrywką katolicyzmu ${ }^{21}$ ". Memorandum o tej samej treści M. Tyszkiewicz złożył do Sekretariatu Stanu w dniu 3 czerwca 1919 r.

Podczas audiencji z papieżem Benedyktem XV w dniu 25 maja 1919 r. hrabia prekazał Ojcu Świętemu pisemny protest przeciwko nadużyciom polskiej armii pod dowództwem generała Józefa Hallera w Galicji. Szczególną uwagę zwrócono na niezgodne z prawem działania polskiej administracji oraz bezprawne aresztowanie księży greckokatolickich ${ }^{22}$. To spotkanie było owocne. Papież rozumiał problemy ukraińskie i wyraził nadzieję, że sprawa ukraińska zostanie rozstrzygnięta zgodnie z zasadami prawa narodów do samostanowienia ${ }^{23}$. Oświadczył hrabiemu, że był „całkowicie po stronie niepodległej Ukrainy i że Wysoka Rada nie wypowiedziała jeszcze swojego ostatniego słowa na temat Ukrainy"24.

W czerwcu 1919 r. Tyszkiewicz spotkał się w Sekretariacie Stanu z kard. Gasparrim. Watykańskie rozmowy Tyszkiewicza koncentrowały się wokół problemu uznania państwa ukraińskiego i wysłania papieskiego delegata na Ukrainę. Omawiano także kwestię położenia Kościoła greckokatolickiego w Galicji Wschodniej w związku z represjami władz polskich, wywołanymi przebiegiem, a zwłaszcza konsekwencjami, wojny polsko-ukraińskiej 1918-1919 r. w Galicji. Przebieg rozmów Tyszkiewicza w Watykanie świadczył o dużym znaczeniu, jakie Benedykt XV przypisywał zapewnieniu Kościołowi greckokatolickiemu możliwości swobodnego działania, zarówno na polu organizacyjnym, jak i duszpasterskim. Papież podkreślał prawo Ukraińców do samostanowienia, zapewniając Tyszkiewicza o szczególnej przychylności Stolicy Apostolskiej dla narodu ukraińskiego. Dyplomata ukraiński umiejętnie podnosił w Watykanie sprawę unii kościelnej, roztaczał przed czułymi na tym punkcie kurialistami perspektywy szybkiej katolicyzacji Ukrainy i ścisłych związków kościelnych ze Stolicą Apostolską ${ }^{25}$.

M. Tyszkiewicz przesłał podobne noty protestu przeciwko polskiej armii i administracji w stosunku do Ukraińców w Galicji w dniu 29 maja oraz 11 czerwca i 18 lipca 1919 r. Protestując w imieniu narodu ukraińskiego przeciwko polskim nadużyciom, hrabia poprosił Ojca Świętego o apel do polskiego rządu o natychmiastowe zaprzestanie „swoich okropnych czynów przestępczych”26.

\footnotetext{
21 Idem 2006, s. 282.

22 Tsvengrosz 1991, s. 6.

23 Khoma 1992, s. 17.

24 TsDIA u Lvovi, 681, op.1, spr. 4, k. 2.

25 Mróz 2004, s. 12.

${ }^{26}$ Gentosh 2006, s. 296-297.
} 
Ukraińska Nadzwyczajna Misja Dyplomatyczna na czele z M. Tyszkiewiczem przyczyniła się do wypracowania pozytywnego stosunku tronu rzymskiego do kwestii ukraińskiej i międzynarodowego uznania państwa ukraińskiego, o czym świadczy list P. Gasparriego wysłany do Symona Petlury.

W podziękowaniu Waszej Ekscelencji za pismo chcę zapewnić, że Stolica Apostolska, czcząc szlachetny charakter narodu ukraińskiego, będzie gorąco się modlić o jego dobrobyt i mocno wierzyć w prawo do samostanowienia, uznawane przez inne narody należące do innych ludów byłego imperium rosyjskiego. Wierzę, że Ukraina skorzysta z tego prawa ${ }^{27}$.

Ważnym osiągnięciem było wysłanie na Ukrainę misjonarza apostolskiego. Wizytatorem apostolskim został Giovanni Genocchi. Jednak z powodu sprzeciwu polskich sił politycznych i działań wojskowych w kraju Genocchi nie był w stanie dotrzeć do celu, ale jego kontakty z przedstawicielami służb dyplomatycznych URL, ukraińskimi organizacjami obywatelskimi i przedstawicielami Kościoła greckokatolickiego pomogły w wypracowaniu stanowiska Watykanu w sprawie ukraińskiej ${ }^{28}$. W wyniku apeli Tyszkiewicza i informacji papieskiego misjonarza Stolica Apostolska planowała udzielić oficjalnego wsparcia Ukraińcom ze wschodniej Galicji w lipcu 1919 r. Z powodu sprzeciwu polskiego rządu, w szczególności protestu premiera Polski Ignacego Jana Paderewskiego i jego gróźb, że polski ambasador Józef Wierusz-Kowalski zostanie odwołany z Watykanu, pomysł ten jednak nie został zrealizowany ${ }^{29}$. Mimo to podczas konferencji paryskiej Tyszkiewiczowi udało się uzyskać poparcie papieża za pośrednictwem jego przedstawiciela - Cerettiego. Umożliwiło to opublikowanie w oficjalnym biuletynie włoskiego Ministerstwa Spraw Zagranicznych artykułu, w którym hrabia zaprzeczył zarzutom rosyjskiej agencji dotyczącym słabości ukraińskiego ruchu narodowo-wyzwoleńczego.

Mimo że oficjalne stosunki ze Stolicą Apostolską nie zostały nawiązane, przyjęcie w Watykanie nadzwyczajnej misji dyplomatycznej URL z M. Tyszkiewiczem można zatem traktować jako uznanie przez Watykan Ukrainy jedynie de facto, a nie de iure, ponieważ nie został dopełniony warunek formalnego aktu uznania Ukrainy i jej rządu przez Stolicę Apostolską na jego notyfikacji. Nie nastąpiła również wymiana przedstawicielstw dyplomatycznych pomiędzy zainteresowanymi stronami ${ }^{30}$.

M. Tyszkiewicz nie pełnił funkcji ambasadora Ukrainy w Watykanie długo. Zgodnie z decyzją rządu URL z lipca 1919 r. został przeniesiony do Paryża jako

\footnotetext{
27 TsDIA u Lvovi, spr. 4, k. 2.

28 Smolii 2001, s. 343.

29 Zięba, s. 90.

${ }^{30}$ Mróz 2004, s. 13.
} 
przewodniczący delegacji ukraińskiej na paryskiej konferencji pokojowej. We wrześniu tego roku przystąpił do wykonania swoich obowiązków.

Nowa nominacja Tyszkiewicza wywołała falę zainteresowania dziennikarzy. Prorosyjskie i propolskie wydania krytykowały go, natomiast prasa paryska zaprzeczyła oskarżeniom i doceniła działania hrabiego. Podczas pobytu w Paryżu znani dziennikarze przeprowadzili z nim sześć wywiadów, a materiały te zostały opublikowane $\mathrm{w}$ trzydziestu wpływowych czasopismach ${ }^{31}$. Przyczyniło się to do tego, że z delegacją ukraińską zaczęto się liczyć, a europejscy politycy zainteresowali się Ukrainą.

Podczas pobytu w Paryżu M. Tyszkiewicz odbył szereg spotkań w kręgach polityki i biznesu i nawiązał przyjazne stosunki z różnymi wpływowymi ludźmi. Wśród nich byli hrabia de Castellane, który miał wpływy w kręgach rządowych Francji, hrabia de Segur i dyplomata ambasady francuskiej w Bernie, hrabia de Chateauneuf, członek holenderskiego parlamentu van Nispen, delegat Stanów Zjednoczonych Ameryki. Hrabia utrzymywał również dobre kontakty z szefem delegacji Królewstwa Serbów, Chorwatów i Słoweńców Nikolą Pašiciem i ministrem spraw zagranicznych tego państwa Antem Trumbiciem, szefem greckiego MSZ Politisem i innymi.

Ogromne znaczenie również miała audiencja hrabiego Tyszkiewicza u marszałka Ferdinanda Focha, wodza Sił Sprzymierzonych w Europie. Jako zwolennik polskiej koncepcji rozwiązania polsko-ukraińskich kontrowersji wokół wschodniej Galicji i osoba negatywnie nastawiona wobec Zachodnioukraińskiej Republiki Ludowej, zainicjował on pomoc wojskową dla Polski - wysłanie armii Józefa Hallera z Francji do Galicjii ${ }^{32}$. Kwestię ukraińską i państwowość URL traktował jednak ze zrozumieniem. „Należy uznać niepodległość Ukrainy”33 - stwierdził marszałek podczas spotkania.

Tyszkiewicz przeprowadził również rozmowy z wybitnymi przedstawicielami świata finansów, w szczególności z Edmondem Fabre-Lucem generalnym dyrektorem banku Crédit Lyonnais, przedsiębiorcą Jeanem Bonardelem, wpływowym ambasadorem Belgii w Bernie, baronem Grottem, i zagwarantował zabezpieczenie przyszłego funkcjonowania francuskim przedsiębiorcom na Ukrainie.

Podczas pobytu w Paryżu skierował on do przewodniczącego konferencji pokojowej cztery noty protestacyjne przeciwko inwazji Denikina na Ukrainę, dwie w sprawie Galicji Wschodniej, trzy - w sprawie więźniów we Włoszech i Niemczech, trzy z prośbą o natychmiastowe uznanie niepodległości Ukrainy i o pomoc

\footnotetext{
31 TsDIA u Lvovi, spr. 4, k. 2.

32 Krasivskyi 2010, s. 162-163.

33 TsDIA u Lvovi, spr. 4, k. 3.
} 
jej $\mathrm{w}$ walce $\mathrm{z}$ wojskiem bolszewickim ${ }^{34}$. Ponadto poruszał te kwestie $\mathrm{w}$ licznych wywiadach opublikowanych w czasopismach prawie wszystkich państw sprzymierzonych.

Działania M. Tyszkiewicza wywołały obawy dobrze zorganizowanej opozycji rosyjskich komisji zagranicznych i ich zwolenników spośród ukraińskich i polskich imigrantów politycznych. Hrabiemu wypowiedziano bezlitosną wojnę i organizowan donosy, intrygi, zatrzymywano delegatów fundacji, bojkotowano go w ukraińskiej prasie - wszystko to w celu sparaliżowania jego wysiłków. Wspierany przez Naczelnego Atamana S. Petlurę, nie cieszył się analogicznym poparciem w ukraińskich kręgach politycznych.

Działania Tyszkiewicza utrudniała także trudna sytuacja finansowa delegacji, która w rzeczywistości nie była dotowana. Przez siedem miesięcy hrabia musiał utrzymywać reprezentację, wypłacając pensje pracownikom, finansując publikacje w znanych francuskich czasopismach z własnych środków ${ }^{35}$.

Jednak społeczeństwo francuskie przyjęło to wyjątkowo przychylnie. Został honorowym członkiem Stowarzyszenia Odbudowy Uniwersytetu w Louvain, wśród których byli także Balfour, Benesz, Lansing, Deschanel, Paderewski i inni światowi liderzy.

Hrabia M. Tyszkiewicz był wielokrotnie przyjmowany przez prezydentów Francji Poincarego i Deschanela, ministra Barthou, przewodniczącego Komisji Spraw Zagranicznych Senatu de Salvę, ministrów, licznych senatorów, członków akademii ${ }^{36}$. Dzięki staraniom Tyszkiewicza deputowany parlamentu Gailhard Barcel dwukrotnie interpelował w Izbie w sprawie uznania niepodległości Ukrainy. Francuskie MSZ, na które mieli wpływ wrogo nastawieni wobec Ukrainy rosyjscy emigranci, wyraziło gotowość uznania niepodległości Ukrainy.

Jako szef ukraińskiej misji w Paryżu hrabia M. Tyszkiewicz odbył szereg spotkań z najbardziej wpływowym politykiem w Anglii Philipem Kerrym, osobistym sekretarzem Lloyda George’a, który oświadczył, że Wielka Brytania jest gotowa uznać niepodległość Ukrainy pod warunkiem, że wojsko i rząd będą miały narodowe terytorium. Tyszkiewicz dostarczył Kerremu materiały na temat sytuacji na Ukrainie, które wywarły na nim wielkie wrażenie. Na prośbę Tyszkiewicza kardynał Gasparri wysłał list do brytyjskiego Ministerstwa Spraw Zagranicznych, zalecając, aby anglojęzyczni politycy katoliccy poparli sprawę ukraińską. List został również wysłany do lidera partii katolickiej w parlamencie Lorda Talbota, który z kolei przekazał go Lloydowi George’owi i Curzonowi ${ }^{37}$.

\footnotetext{
34 Ibidem, spr. 5, k. 22.

35 Ibidem, spr. 21, k. 13.

36 Ibidem, k. 31-32.

37 Krasivskyi 2012, s. 135.
} 
O zaangażowaniu M. Tyszkiewicza w sprawę ukraińską świadczy jego korespondencja z S. Petlurą. Niektóre oryginały listów znajdują się w Centralnym Państwowym Archiwum Historycznym we Lwowie. Rzucają one światło na trudny okres walki o ukraińską państwowość i rolę M. Tyszkewicza na tej drodze. W jednym z listów z 6 stycznia 1921 r. Symon Petlura napisał:

Z poczuciem prawdziwej wdzięczności i z wielką przyjemnością stwierdzam, że przez cały czas pan stanowczo występował po stronie naszej państwowości, nie opuszczając flagi w najtrudniejszych momentach dla URL. Zrobił pan wszystko, co w pana mocy nawet w niesprzyjających warunkach ${ }^{38}$.

Jego praca dyplomatyczna została doceniona przez Ministerstwo Spraw Zagranicznych URL. W piśmie do hrabiego stwierdzono, że Ministerstwo Spraw Zagranicznych „uważa Pana za jednego z pierwszych patriotów w dziedzinie odrodzenia narodowego, który pomimo wszelkich przeszkód, nie żałując swoich wysiłków, dążył do najwyższego ideału narodowego: walki o wolną, niepodleglą Ukrainę"39.

W fundacji Tyszkewicza znajdują się także listy od A. Szeptyckiego, M. Hruszewskiego, D. Doncowa, M. Efremowa, D. Lewickiego, K. Lewitskiego i innych znanych ukraińskich postaci politycznych i religijnych. Dmytro Lewicki, szef misji dyplomatycznej w Szwecji i Norwegii, wyraził zrozumienie i poparcie dla działań hrabiego w zakresie ochrony interesów Ukrainy. Lewicki zaznaczał:

Piszę do pana jako do Ukraińca i wyrażam moją szczerą wdzięczność za wielkie sukcesy ukraińskiego biznesu za granicą, które stały mozliwe dzięki Panu. Wpływ, jaki wywiera Pan na dyplomację w Paryżu, znajduje swoje odzwierciedlenie i u nas, co znacznie ułatwia moją pracę ${ }^{40}$.

Ze szczerymi wyrazami wdzięczności za pracę Tyszkiwicza po jego rezygnacji Doncow powiedział: „Byłoby lepiej, gdyby przewodniczącym naszej polityki w końcu przyszło do głowy, zostawić Pana w Paryżu”41. Analizując przyczyny dymisji, S. Efremow powiedział: „Biada nam, jeśli nie zbudujemy państwa ukraińskiego z powodu naszych własnych drobnych intryg"42.

Wśród przyjaciół i sympatyków M. Tyszkiewicz był znany jako ukraiński patriota, który twierdził: „Służę Ukrainie, wolnej i niepodległej, a moim obowiąz-

\footnotetext{
${ }^{38}$ Spr. 18, k. 37.

39 Spr.17, k. 48.

${ }^{40}$ K. 13.

${ }^{41}$ Spr. 16, k. 69.

${ }^{42}$ Spr. 15, k. 74.
} 
kiem jest bronić jej aż do ostatniej chwili życia”33. W liście do ukraińskiego rządu hrabia napisał: „Z obolałym sercem patrzę na straszną tragedię naszego ludu i mogę was zapewnić, że nigdy go nie opuszczę, bo kocham ten naród jak własną duszę" ${ }^{\prime 4}$. Polska prasa często oskarżała go o zdradę polskich interesów. Podobne zarzuty słyszał z ust członków rodziny. W odpowiedzi Tyszkiewicz pisał:

Uważać się za Rusina [Ukraińca - O.K.] czy Polaka, będę sam decydować. Historia mnie uniewinni, a może najbliższa przyszłość. Żaden z polskich historyków nie uważa rodziny Tyszkiewiczów za Polaków. Odrzucenie istnienia narodu rusińskiego (ukraińskiego) i litewskiego jest zaprzeczeniem podstawowych zasad starożytnej Polski, dowodem bezprecedensowego upadku jej ideałów, dowodem absolutnej ignorancji. (...) Wybrałem ciernistą drogę obrony mojego kraju i ludzi, którzy pozostali w tyle. Podążając śladami metropolity Szeptyckiego i z podniesioną głową będę kontynuował iść tą drogą. Nie każdy jest w stanie to poczuć lub zrozumieć ${ }^{45}$.

Po upadku rewolucji ukraińskiej i w związku z zawarciem polsko-radzieckiego traktatu pokojowego z 18 marca 1921 r. M. Tyszkiewicz, nie mogąc wrócić do rodzinnej Andruszówki, pozostaje z rodziną w Polsce. Mieszka w Bydgoszczy, Żydowie, Gnieźnie. Dużo pracuje nad uporządkowaniem swoich wspomnień, które zaczął publikować w 1928 roku. W jednym z numerów czasopisma „Literacki Biuletyn Naukowy” („Literaturno-Naukowyj wisnyk”), analizując życie kulturalne Ukrainy XIX wieku, Tyszkiewicz docenia dorobek pisarzy polskich: Bohdana Zaleskiego, Seweryna Goszczyńskiego, Leonarda Sowińskiego, Aleksandra Grozy i Juliusza Słowackiego, którzy przyczynili się do polsko-ukraińskiego porozumienia, wnieśli znaczący wkład $\mathrm{w}$ badania kultury i historii Ukrainy i jej popularyzację ${ }^{46}$. W swoich wspomnieniach z 1928 r. pisał także o przygotowaniu rękopisu $\mathrm{w}$ trzech tomach o stosunkach polsko-ukraińskich, który „zaginął w czasach reżimu bolszewickiego" ${ }^{47}$. Niektóre ze swoich artykułów historycznych Tyszkiewicz publikuje w miesięczniku „Kronika Czerwonej Kaliny” („Litopys Czerwonoi Kalyny”), wydawanym od 1930 r. we Lwowie ${ }^{48}$. W wolnym czasie rysuje. Stara się przede wszystkim odnowić portrety zniszczone podczas rewolucji na Ukrainie. Namalowany przez niego obraz św. Antoniego znajduje się w kościele w Żydowie. Nie ma informacji o jego zaangażowaniu w życie społeczno-polityczne Polski. Wiadomo jednak, że działał w tutejszym ukraińskim środowisku emigracyjnym.

\footnotetext{
${ }^{43}$ Ibidem.

${ }^{44}$ Spr. 21, k. 3.

${ }^{45}$ Spr. 5, k. 12.

46 Stryjek 2012, s. 42.

47 Ibidem, s. 43.

${ }^{48}$ M.O. 1930, s. 6.
} 
M. Tyszkiewicz zmarł 3 maja 1930 r. w Gnieźnie i został pochowany w kościele w Żydowie w rodzinnym grobie Chełmickich, gdzie później pochowano też jego żonę Sofię, syna Jerzego i synową Leontinę. W artykule redakcyjnym „Literackiego Biuletynu Naukowego” („Literaturno-Naukowy Wisnyk”) o M. Tyszkiwiczu piszą jako o „jednej z najbardziej charakterystycznych postaci najnowszego ruchu ukraińskiego (...), która łączy dwie epoki, dwie klasy i dwie tradycje kulturowe ${ }^{49}$.

Po śmierci hrabiego jego rodzina mieszkała w Bydgoszczy i wkrótce przed wrześniem 1939 r. przeprowadziła się do Żydowa. Przeprowadzka ta uratowała ich przed śmiercią na początku okupacji niemieckiej. Władze niemieckie zamierzały zniszczyć polskich działaczy społeczno-politycznych na zdobytych terytoriach należących do Rzeszy. Przeniesienie się Tyszkiewiczów z Bydgoszczy do Żydowa, gdzie nikt ich nie szukał, uratowało im życie.

\section{BETWEEN UKRAINE AND POLAND: SOCIAL AND POLITICAL ACTIVITIES OF COUNT M. TYSZKIEWICZ (1857-1930)}

\section{Summary}

Michał Tyszkiewicz became a person who reconciled the interests of the Polish and Ukrainian nations, and actively advocated independence of Ukraine. As a wealthy individual, he supported young Ukrainians financially, paid school fees for numerous talented children from poor backgrounds, spent money to ensure periodicals for peasants, published Ukrainian books and made financial contributions to various publications. During World War I, the count lived in Western Europe, where he actively championed the Ukrainian cause and attempted to refer the matter of Ukrainian independence to those who had decisive influence on international politics. For this end, Tyszkiewicz built up contacts with French and British diplomats, published articles concerning history of Ukraine, called for the release of Sheptytsky from Russian exile. In February 1919, he was appointed the head of the diplomatic mission to Vatican. The efforts of the Special Ukrainian Diplomatic Mission he was in charge of encouraged Vatican to adopt a favourable stance towards the Ukrainian cause and international recognition of the Ukrainian state. As of August 22 ${ }^{\text {nd }}, 1919$, M. Tyszkiewicz headed the Ukrainian mission to the Peace Conference in Paris, where he held a number of business meetings and established friendly relationships with a range of influential persons from Great Britain, France, the Netherlands, the United States and other countries, as well as with well-known politicians, among whom he promoted the Ukrainian cause and sought recognition of Ukraine's independence.

\section{Bibliografia}

Cherkaska H. 2015, Hraf Mykhailo Tyshkevych [online]. UA History [dostęp: 2015-28-04]. Dostępny w Internecie: <http://uahistory.com/topics/famous_people/2195>.

Chykalenko Y. 2005, Shchodennyk (1918-1919), Kyiv.

${ }^{49}$ Literaturno-Naukovyi Visnyk 1930, s. 834. 
Hentosh L. 2000, Dyplomatychni kontakty Ukrainskoi Narodnoi Respubliky z apostolskoiu stolytseiu v 1919-1921 rokakh konteksti skhidnoi polityky rymskoi kurii, [w:] Ukraina moderna za 1999-2000 rr., 4-5, Lviv, s. 168-169.

Hentosh L. 2006, Vatykan i vyklyky modernosti. Skhidnoievropeiska polityka papy Benedykta KhV ta ukrainsko-polskyi konflikt u Halychyni (1914-1923), Lviv.

Hospodyn A. 1989, Try vyznachni dyplomaty [online]. Diasporiana [dostęp: 2015-28-04]. Dostępny w Internecie: <http://diasporiana.org.ua/istoriya/53-gospodin-a-tri-viznachni-diplomati/>.

Khoma I. 1992, Apostolskyi Prestil i Ukraina v 1919-1922, Rym.

Krasivskyi O. 2010, Stosunki ukraińsko-polskie w latach 1917-1923, Poznań-Gniezno.

Krasivskyi O. 2012, Dyplomatychna diialnist M. Tyshkevycha v period vidrodzhennia Ukrainskoi derzhavy (1919-1920), [w:] S. Tyszkiewicz i W.Wasylenko (red.), Michał Tyszkiewicz, 18571930. Człowiek i polityka, Warszawa, s. 130-136.

Lekhniuk R. 2014, Hraf Mykhailo Tyshkevych: vid kraiovstva do modernoho ukrainstva Intermarum: istoriia, polityka, kultura [online]. Nacionalna biblioteka Ukrajiny [dostęp: 2015-28-04]. Dostępny w Internecie: <http://nbuv.gov.ua/UJRN/inhpc >.

Lekhniuk R. 2015, Spohady Mykhaila Tyshkevycha yak dzherelo do vyvchennia ukrainskoho konserwatyzmu, Aktualni problemy vitchyznianoi ta vsesvitnoi istorii, 15, s. 143-156.

Literaturno-naukovyi vistnyk, 1930, 9.

M.O. 1930 [psevdonim M. Tyshkevycha]. Napoleon i Ukraina, Litopys Chervonoi Kalyny, 1930, 5b.

Mróz M. 2004, Watykan i Ukraina w okresie kształtowania się systemu wersalskiego w latach 19181921, Dzieje najnowsze, 36, s. 3-19.

Shemshuchenko Yu. (red.) 2002, Ukrainskyi pravnychyi almanakh, Kyiv.

Smolii V.A. (red.) 2001, Narysy z istorii dyplomatii Ukrainy, Kyiv.

Stryjek T. 2012, Michał Hr. Tyszkiewicz (1857-1930), [w:] S. Tyszkiewicz i W. Wasyłenko (red.), Michał Tyszkiewicz - losy i tożsamość, 1857-1930, Warszawa.

Tsentralnyi derzhavnyi istorychnyi arkhiv Ukrainy u Lvovi (TsDIA Ukrainy u Lvovi), sygn. 681 (Mykhailo Tyshkevych), opis 1, sprawa 4, 5, 6, 15, 16, 17, 18, 21.

Tsvenhrosh H. 1991, Apostolskyi prestol i mytropolyt Sheptytskyi, Lviv.

Tyshkevych M. 1928, Uryvky z spohadiv, Literaturno-naukovyi visnyk, 7-8, 9.

Tyszkiewicz S. 2012, Początki historii rodu Tyszkiewiczów Hrabiów na Łohojsku i w Berdyczowie. Referat wygłoszony na zjeżdzie rodziny Tyszkiewiczów w Łukęcinie w dniu 8 wześnia 2002 r., [w:] S. Tyszkiewicz i W. Wasylenko (red.), Michał Tyszkiewicz, 1857-1930. Człowiek i polityka, Warszawa, s. 171-177.

Vasylenko V. 2012, Hraf Mykhailo Tyshkevych (1857-1930). Na poli ukrainskoho derzhavotvorennia, [w:] S.Tyszkiewicz i W.Wasylenko, (red.), Michał Tyszkiewicz, 1857-1930. Człowiek i polityka, Warszawa, s. 171-177.

Zięba A. 1994, Watykan i Ukraina po I wojnie światowej, Warszawskie Zeszyty Ukrainoznawcze, 2, 1994, s. 87-95. 